\title{
The Ties that Bind
}

\section{Smallness, Nonsovereignty, and Political Reform in St. Eustatius}

\author{
Wouter Veenendaal* \\ KITLV/Royal Netherlands Institute of Southeast Asian and Caribbean Studies, \\ Leiden, The Netherlands \\ veenendaal@kitv.nl
}

\begin{abstract}
Whereas small island territories are known to face a variety of obstacles to democracy and good governance, it is largely unclear if a nonsovereign relationship with a larger metropolitan country can alleviate these challenges, and which constitutional status provides the best results in this regard. This article aims to address these questions by providing an in-depth case study of St. Eustatius, a Dutch Caribbean island that in 2010 was politically integrated into the Netherlands as a public entity or special municipality. Based on two weeks of field research consisting of nineteen in-depth interviews with a variety of respondents on the island, the article finds that the changes of 2010 have not been able to function as a remedy to the profuse governance problems on the island, while the increased Dutch involvement and dominance have resulted in widespread frustration and resentment.
\end{abstract}

\section{Keywords}

nonsovereignty - smallness - comparative politics - Dutch Caribbean - political institutions - qualitative methods - St. Eustatius

* I thank the two anonymous reviewers for their useful comments and suggestions, which have greatly improved this article. In addition, I would like to express my gratitude to the many people on St. Eustatius whom I talked to, and who generously shared their knowledge and expertise about Statian politics with me. This work was supported by the Dutch Organisation for Scientific Research (NWO), grant number 858.14.012.

(C) WOUTER VEENENDAAL, 2016 | DOI: 10.1163/22134360-09003055

This is an open access article distributed under the terms of the Creative Commons

Attribution-Noncommercial 3.o Unported (CC-BY-NC 3.0) License. 
On October 10, 2010, an extensive political reform was effected in the Caribbean parts of the Kingdom of the Netherlands. The autonomous "country" of the Netherlands Antilles was dismantled, and the five islands of this federally organized nonsovereign unit each acquired a new political status, and a direct political relationship with the metropolitan Netherlands. The two demographically largest islands, Curaçao and St. Maarten, both became autonomous countries in the Kingdom on their own, a status that had already been conferred to the island of Aruba in 1986. The three smallest islands, Bonaire, St. Eustatius, and Saba (BES islands), became public entities of the European Netherlands, and were constitutionally and politically integrated with the metropolis. The latter development represents a profound break with Dutch colonial and postcolonial traditions and policies because, in contrast to France and the United States, until the 1990s the Netherlands never played an active political role in its overseas territories (Oostindie \& Klinkers 2003:57, 92). ${ }^{1}$ The political integration of the three smallest Dutch Caribbean territories can in many ways be compared to the postwar French decolonization policy, and creation of the French Collectivités d' Outre Mer (coms) and Départements d' Outre Mer (DOMs; Veenendaal 2015).

The breakdown of the Netherlands Antilles and the establishment of direct political relations with the Netherlands were anticipated with high hopes on the three small islands. This was particularly inspired by their long-standing desire to be released from the dominance of Curaçao, which, being the most populous island, held the seat of the Antillean government and parliament. In addition, people on the islands hoped that political integration with the Netherlands would bring them a higher standard of living, as well as entitlement to Dutch social welfare provisions. Five years down the road, the hope and expectations have largely given way to frustration and resentment. On Bonaire and St. Eustatius a number of referendums have been held as part of attempts to change the political status, and on all three islands Dutch dominance and interference are broadly resisted. The situation is worst on St. Eustatius, which in June 2015 was placed under higher administrative supervision by the Dutch government because of alleged financial mismanagement and a lack of good governance. This decision was rejected by the political executive of the island, which even made an appeal to the United Nations to complain about the supposed illegality of Dutch decolonization policies on the island.

Using the island of St. Eustatius as a case study, this article seeks to examine how political integration with the Netherlands has affected the characteristics

1 Oostindie and Klinkers (2003:57) refer to this tradition as "careless colonialism." 
of local politics, democracy, and governance in St. Eustatius. While virtually all scholarly research on the Dutch overseas territories focuses on the relationship between the European Netherlands and the Caribbean parts of the Kingdom (Duijf \& Soons 2011; Hillebrink 2008; Oostindie \& Klinkers 2012), this article takes a novel approach by examining local political dynamics in one particular Dutch Caribbean island. The case of St. Eustatius is analyzed and described in the context of ongoing academic debates about nonsovereignty, smallness, and postcolonialism, and toward the end of the article the theoretical implications of this particular case are highlighted and discussed. Having recently been placed under financial supervision, St. Eustatius can be regarded as a crucial case for examining the effect of a change in political status on the characteristics and quality of governance. The results of this analysis reveal that the amplified political role of the metropolitan Netherlands on the island has primarily resulted in dissatisfaction and resentment, while the 2010 reforms have not (yet) been able to mitigate the political problems caused to a large extent by the mutually reinforcing effects of smallness and insularity.

This article is based on two weeks of field research on St. Eustatius in June 2015, immediately after closer financial supervision of the island was put in place by the Dutch government. As part of this field research, nineteen indepth, semistructured interviews were held with St. Eustatian island council members (i.e., parliamentarians) representing the various political parties, commissioners (i.e., members of the executive), journalists, and other public figures, as well as with officials working for the Dutch government on the island. ${ }^{2}$ In addition, newspapers, public documents, and secondary literature sources were examined in order to triangulate the findings, and to function as a check on the interview data. After providing a brief overview of the existing literature on politics in small, nonsovereign island jurisdictions (SNIJs), the article introduces the case of St. Eustatius, and subsequently presents the findings of the field research. In the conclusion, these findings are connected to the broader academic literature.

2 One of the criteria in the selection of interviewees was variation in political views, especially with regard to the political status of St. Eustatius, and in the later sections of this article I will present interview excerpts to illustrate or buttress my arguments. Due to the close interpersonal relations and lack of political anonymity in small island jurisdictions, in most cases the respondents who were quoted remain anonymous. 


\section{The Literature on Politics and Governance in Small, Nonsovereign Island Jurisdictions}

In recent years, a variety of studies on small, nonsovereign island jurisdictions have appeared. ${ }^{3}$ Most of these studies discuss the advantages and disadvantages of an enduring nonsovereign relationship from the perspective of overseas territories, and in this context refer to ongoing status debates and recurrent status referendums in these jurisdictions. While some reference is made to local politics, relatively few publications explicitly discuss the characteristics and dynamics of politics, democracy, and governance within nonsovereign territories. Since a wide majority of these jurisdictions are island nations and have a small or very small population size, insularity and smallness are likely to have a significant impact on local politics in overseas territories (Veenendaal 2016). While nonsovereign territories differ with respect to their specific constitutional status and relationship with the metropolis, the extent to which these differences affect the broader dynamics of their domestic politics is largely unclear.

According to the academic literature, smallness and insularity have a profound, and to a certain extent mutually reinforcing, effect on politics and democracy. More direct and frequent contacts between citizens and politicians in small island societies entail that politics is very personal in nature, and that interpersonal relations influence political developments to a large extent. On the positive side, smallness and insularity allow politicians to acquire a better overview of the preferences and demands of their constituents, which is supposed to enhance political representation (Anckar 2002; Diamond \& Tsalik 1999). In addition, the proximity between voters and their political representatives increases the political attachment, awareness, and participation of citizens, resulting in higher levels of voter turnout, for example (Remmer, 2010). Finally, according to some scholars smallness also increases feelings of solidarity among citizens of small island states, which results in more consensual, harmonious, and stable politics (Congdon Fors 2014; Lijphart 1977:61-65).

The close and personal connections between citizens and politicians in small island units also create problems, however. In the first place, overlapping private and professional relationships generate conflicts of interests, and may therefore result in transgressions on the part of politicians. In particular, the strongly personal contacts create a tendency to patron-client linkages in small island settings, in the sense that political support is often exchanged for

3 Aldrich \& Connell 1998; Baldacchino \& Milne 2006, 2009; Bonilla 2015; Clegg \& Killingray 2012; Ramos \& Rivera 2001; Rezvani 2014. 
material benefits or jobs in the public sector (Chittoo 2011; Farrugia 1993; Sutton $2007 \mathrm{~b}$ ). Second, since voting behavior in small, insular jurisdictions is usually based on personal and particularistic considerations rather than programmatic or policy-related preferences, substantive political representation may actually be undermined (Richards 1982; Veenendaal 2013). The prevalence of personalistic instead of ideological forms of competition potentially also creates instability, because personal conflicts can easily transform into political ones, and the lack of ideological attachments can result in more frequent party split-offs and government collapse. Finally, various scholars have noted that the political executive of small island units commonly assumes a dominant position vis-àvis institutions such as parliament, the news media, the judiciary, the private sector, and civil society organizations (Sutton 2007a). Together, these factors entail that despite their formally democratic institutions, small island societies are often beset by a variety of remarkably authoritarian political dynamics (Baldacchino 2012; Veenendaal 2014).

The nonsovereign status entails that politics in overseas territories is, to varying degrees, supervised and constrained by the metropolitan government. While the French overseas territories have been fully integrated with the metropolis and therefore experience considerable metropolitan oversight, the overseas territories of Denmark and New Zealand traditionally have more autonomy, and by extension face less metropolitan supervision (cf. Aldrich \& Connell 1998). Before 2010, the Dutch Caribbean islands enjoyed a relatively large measure of autonomy, but the political integration of Bonaire, St. Eustatius, and Saba has considerably strengthened the supervisory role of the Netherlands on these islands. A brief survey of governance dynamics in small, overseas territories reveals that in virtually all small, nonsovereign island jurisdictions, local government is often negatively affected by smallness and insularity (cf. Clegg \& Gold 2012:26-27; Daniel 2005:60; De Jong 2009:33). Ank Klomp's excellent study on Bonaire (1983) reveals that on this island as well politics is strongly influenced by personal relations and patron-client linkages, which Klomp refers to as "machine politics." Recent maladministration problems in the Turks and Caicos Islands (UK), French Polynesia (France), St. Maarten (The Netherlands), the Cook Islands (New Zealand), and the US Virgin Islands (USA) suggest that the inherent political problems of small island societies are not related to a particular political-constitutional status (Hintjens 1997). Furthermore, these developments also reveal that nonsovereignty in itself does not provide an effective bulwark against the governance problems associated with smallness and insularity.

Metropolitan oversight of local politics, and the ensuing safeguarding of human rights, democracy, and the rule of law is one of the advantages of 
nonsovereignty highlighted in the literature (Oostindie \& Klinkers 2003). In addition to this, various scholars have highlighted the economic, financial, and security benefits that nonsovereign territories can reap from a long-term attachment to a larger metropolis, as well as the opportunities that arise from having the nationality and passport of a larger and often more developed mother country (Baldacchino \& Milne 2006; Hintjens 1997; Rezvani 2014). These material benefits are, however, habitually counterbalanced by a variety of more intangible and ideational disadvantages. The lack of autonomy and the ongoing metropolitan control often result in frustration and resentment toward the metropolis, particularly in the context of a postcolonial relationship (Allen 2010; Hall 2005). In the Caribbean, the historical trauma of slavery adds a racial element to these sensations, and generates a discourse in which nonsovereignty is recurrently linked to colonialism, racism, and oppression. Furthermore, the populations of overseas territories are often not adequately represented in the metropolitan political institutions, creating various democratic deficits (Corbin 2012b). In sum, the debate about the relative merits and disadvantages of nonsovereignty can largely be seen as a head versus heart dilemma, in which nonsovereignty can be regarded as a strategically pragmatic and rational, yet psychologically and ideologically unsatisfactory outcome.

\section{The Case of St. Eustatius and the Reforms of "10-10-10"}

With a territory of $21 \mathrm{~km}^{2}$ and a total population of approximately 4,00o, St. Eustatius (affectionately called "Statia" by locals) is one of the smallest nonsovereign jurisdictions in the world. ${ }^{4}$ The island is located in the northeastern Caribbean, immediately to the northwest of larger St. Kitts, and to the southeast of smaller Saba. In the late eighteenth century the island was an important transit port in the slave trade, and on November 16, 1776, the Governor of the island, Johannes de Graaff, was the first foreign leader to recognize the sovereignty of the United States by offering the "First Salute" to the crew of an American ship (Ayisi 1995:24-25; Van den Bor 1979:9-12; Roitman \& Jordaan 2015). In this period of progress and wealth, the island was known as the "Golden Rock," and in 1790 the population of St. Eustatius exceeded 8,00o, more than twice what it is today. The decline of the Dutch West India Company (WIC), the end of the special economic position of the island, and the abolition of slavery in the mid1800 all contributed to the economic decline on the island, which by 1850 had become an impoverished and economically dependent backwater (Van den

4 Although the island is part of the Kingdom of the Netherlands the lingua franca is English. 
Bor 1979:13). The island's one-time historical prominence occupies an important place in the imagination of the Statian population, and on the island many monuments and plaques commemorate its erstwhile glory.

Until 2010, St. Eustatius formed part of the nonsovereign "country" of the Netherlands Antilles, which, after the separation of Aruba in 1986, consisted of the two southern Caribbean islands of Bonaire and Curaçao, and the three northeastern Caribbean islands of Saba, St. Eustatius, and St. Maarten. Within this five-island unit, St. Eustatius played a role that some described as a bridge between the other islands (cf. Oostindie \& Klinkers 2012:153), and others as never taking a stand and therefore never causing trouble (Sluis 2004:30). As one of the smallest and economically least developed islands, St. Eustatius was financially dependent on the compensation it received from the Antillean government in Curaçao, which might explain its passive role within the nonsovereign federation. A status referendum on St. Maarten in 2000, which resulted in a wide popular majority for the island becoming a separate country within the Kingdom, marked the dismantling of the Netherlands Antilles (Duijf \& Soons 2011:55). In subsequent status referendums on the other islands, the population of Curaçao also voted for country status, while wide majorities on the islands of Bonaire and Saba voted for "direct ties" with the Netherlands. On St. Eustatius, the referendum of April 8, 2005 resulted in a wide majority (nearly 75 percent of voters) opting to stay within the Netherlands Antilles. Since all the other islands rejected this option, however, the Statian politicians subsequently joined their Bonairean and Saban counterparts in the negotiations that culminated in the political integration of their island with the metropolitan Netherlands. ${ }^{5}$

Various studies have questioned the legality of the current status of St. Eustatius as a public entity, and have argued that it is incompatible with international law and the United Nations principles of self-determination (Corbin 2012a; Duijf \& Soons 2011; Hillebrink 2008:352). According to these studies, the population of St. Eustatius never officially approved or sanctioned its status as a public entity. In December 2014, on the initiative of a number of civil society groups, a new status referendum was held, which failed to meet the required voter turnout level of 60 percent. With a turnout of 45.5 percent, just over 65 percent of voters expressed a preference for "autonomy," while nearly 33 percent of voters cast a ballot in favor of the current public entity status. In Septem-

5 The islands do not yet form part of the European Union, however, and there is an ongoing discussion about their status with regard to the EU. At present the islands are "overseas countries and territories" of the EU, but in the future they might become "outermost regions," like the French Caribbean territories. 
ber 2015, a four-member delegation from the St. Eustatius island government met with the United Nations Decolonization Committee to discuss the current status of the island, and to request intervention from the United Nations in Dutch decolonization policies. So far, these initiatives have not resulted in any concrete actions by the United Nations.

On October 10, 2010 ("10-10-10"), together with Bonaire and Saba, St. Eustatius was integrated into the metropolitan Netherlands as a public entity or "special municipality." The Antillean constitution and other laws were replaced by Dutch ones, the Antillean guilder was replaced by the US dollar, ${ }^{6}$ and, with some modifications, the Dutch administrative municipal model was implemented on the islands (Wet openbare lichamen Bonaire, St. Eustatius en Saba, 2010). In addition, the Dutch ministries started to implement Dutch governmental policies on the islands, through a new shared service organization called the RCN (Rijksdienst Caribisch Nederland), with headquarters on Bonaire. Finally, a special Kingdom Representative (Rijksvertegenwoordiger) was appointed to function as an administrative link between the islands' local administrations and the central Dutch government, and to coordinate and streamline the cooperation between these institutions. In various ways, the political integration of the three islands constitutes a dramatic shift in Dutch decolonization policy, and can be compared to the French postwar policy of "Départementalisation" by means of which the larger French territories in the Caribbean were integrated into metropolitan France. While the population of the three islands has now gained almost all the political rights of regular Dutch citizens (e.g. the right to vote for the Dutch parliament), the 2010 reforms have significantly decreased the political autonomy of the islands.

While the reforms of 2010 were anticipated with high hopes in both the metropolitan Netherlands and on the islands, five years later dissatisfaction and resentment are the prevailing sentiments. In October 2015 the Dutch government presented its evaluation of the public entity status, which concluded that, whereas progress could be noted in certain policy areas (especially health care and education), in a broader sense the results of the 2010 reforms must be considered a disappointment (Spies et al. 2015). Over the past five years the cost of living has sharply increased, resulting in increased poverty. In addition, the islands have experienced a large influx of Dutch civil servants and citizens, creating social tension and obvious inequalities between wealthy Dutch immigrants and the poorer local populations. Among the Saban and Statian

6 The decision for these islands to adopt the US dollar instead of the euro (which is the currency used in the European Netherlands) was primarily based on trade-related issues and tourism; since the main trade partners of the Dutch Caribbean islands use the American dollar, the introduction of the euro was believed to create undue exchange rate risks. 
populations, the establishment of the RCN on Bonaire generated a new sense of dependence on this larger island, located goo kilometers to the south. Finally, the unsolicited introduction of liberal Dutch laws on abortion, same-sex marriage, prostitution, soft drugs, and euthanasia was strongly opposed by the island populations.

While the 2010 reforms are generally begrudged on all three islands, disappointment and resentment are strongest on St. Eustatius, which is the central case considered in the present article. In June 2015, the island was placed under financial supervision by the Dutch government in reaction to alleged financial mismanagement and wider problems in the sphere of good governance. As the island with the most political tension and the greatest governance weaknesses, St. Eustatius offers the best insights into the effects of the recent political integration on governance and local politics. As a result, it can be seen as a crucial case for the broader theoretical assumption that the type of political status and the degree of autonomy from the metropolitan country have little effect on the quality of democracy, administration, and governance. In the following section, the findings of the field research in St. Eustatius are presented and discussed.

\section{Politics and Democracy on St. Eustatius in the Aftermath of 10-10-10}

As mentioned above, within the Netherlands Antilles the island of St. Eustatius had a reputation for being weak, passive, and dependable. In the handful of studies that have been published about the island, this image is corroborated: according to Wout van den Bor, the island appears to be consumed by "a spirit of passivity and resignation" (Van den Bor 1979:18). The supposed lack of initiative among the Statian population is often attributed to the events of the early nineteenth century, which supposedly continue to exert a psychological effect, and have resulted in a steadfast belief that the Statians are victims of structural forces beyond their control (Van den Bor 1979:306). In an interview, the island governor of St. Eustatius explained how the inert attitude and behavior of island politicians has historically undermined the position of the island:

We have known several politicians that were less aggressive in pursuing objectives for St. Eustatius. So we were always known as the island that would support the coalition, that would be fighting to keep the coalition together; ... we were the only ones that voted to stay within the Netherlands Antilles while everybody else wanted out. It shows that the role that we traditionally played was one of trying to keep folks together even if it meant that we would not put our own agendas first. 
While some observers relate the current state of affairs on St. Eustatius to the events of the late eighteenth and early nineteenth centuries, others highlight sociological or cultural explanations. According to Eric Ayisi, for example, the alleged passivity of the Statian population is primarily the result of a welfare culture:

The Statians are not ungrateful people, but modern Statia is a welfare state. Things are done for them and they in return are not expected to do anything. Their philosophy is not what they will do for St. Eustatius, but what they will get out of the fact of being Statians. This welfare mentality permeates the whole social fabric, and deviation is minimal.

AYISI 1995: xiv

The apathetic reputation of St. Eustatius stands in stark contrast to that of its sister island Saba whose inhabitants are known for their resilience, efficacy, creativity, and determination. When asked about this difference, respondents mostly pointed to the stark historical differences between the islands, and claimed that the islands are incomparable because of their different historical trajectories. According to one politician, however:

We are twenty years behind Saba, in every sense of the word. You know, as a politician who was born here, I am not proud to say it. They run a better administration ... I think the biggest problem here is, besides friends and favors, that you have people elected and appointed in charge of the daily administration as commissioners, that do not understand business. When you go in there, and you don't know what you want, you don't know what you need; I think that is the biggest problem.

As this quote mentions ("friends and favors"), the upshot of the passive and dependable attitude of the island population has been the pervasiveness of patron-client relationships between citizens and politicians in the domestic politics of St. Eustatius (Ayisi 1995:68-74; Van den Bor 1979:311-15). Clientelism is a ubiquitous feature of politics in small societies around the world, and St. Eustatius is no exception in this regard. Reflecting on his own position in Statian society, and his relationship with his constituents, one island council member said:

People know me. Whether they have seen me in the news or on the television, for some reason they know me. And people walk up to me and sometimes they stop me. For example if I go down to a restaurant with 
my family, and people would see me, they stop me. I don't have a problem with it, because I enjoy doing that and speaking with the people. But sometimes there can be awkward moments as well, it really depends on the circumstances ... Of course the people on the island know the power of their vote, so at times it can be demanding.

The quote accurately reveals that, as in other small island societies, personal contacts between politicians and citizens often translate into requests for help or favors from politicians. As in other small Caribbean island states, Statian politicians are widely expected to deliver particularistic benefits to their constituents, such as money, food, loans, permits, or jobs in the public sector. In this regard, another island council member indicated that voting behavior on St. Eustatius is often based on expected rewards in the future:

Because the island is small, you get to meet the politician. And when you cast your vote, you feel "OK, I vote in this way also because I know this person will do something for me, because I know him also."

The extremely small population of St. Eustatius entails that family relations often have a profound effect on politics, because people typically vote for their relatives. There are a limited number of large families on the island, and candidates for office who are members of one of these large families generally have an in-built advantage at the polls. On the other hand this means that political affiliations are often deduced from family connections, which means that family membership can result in either preferential treatment or exclusion from certain benefits. One journalist I interviewed explained that:

We have a lot of family and friends, and so you would know who is voting for which party. So it sometimes kind of influences, for example, if you apply for a job. "You didn't vote for my party, you voted for another party," you know, so those are the effects on a small island. Because everybody knows everybody.

While the family-oriented, personal, and decidedly nonprogrammatic nature of Statian politics might perhaps be expected to generate a more harmonious or consensual political environment, in fact the exact opposite is true. Small societies are often assumed to be more homogenous, and therefore more cooperative or amicable in nature (Anckar 1999; Dahl \& Tufte 1973), but the inhabitants of St. Eustatius are sharply divided along political and religious lines. According to Eric Ayisi (1995:109): 
Although there is no violence on the island, dissensions among individuals or groups of people run rampant. A personal disagreement or quarrel with another person is sometimes taken to ludicrous lengths.

Various interviewees indicated that religious differences have a divisive impact on Statian society. The population of St. Eustatius can broadly be separated into three religious groups: Roman Catholics, Methodists, and Seventh-Day Adventists. The third group especially is seen as having a profoundly negative influence on the unity of the Statian population, because Adventists tend to be very endogamous and in-group oriented, while their attitude toward other religious groups is mostly quite hostile (Van den Bor 1979:213-14). Furthermore religious splits also translate into political divisions, according to most interviewees. One politician argued:

You asked me if religion influences politics here, and I think that is definitely the case. If you look at it, especially the Adventists are politically very active, and they will support politicians who have the same faith. It really depends on who the leader of the party is, and what his religious affiliation is.

As with religion, Statian politics is divisive, polarized, and antagonistic. The island has a multiparty system, and the most recent elections in 2015 were contested by no fewer than six parties, ${ }^{7}$ three of which gained representation on the island council (see results in Table 1). The traditionally dominant group on the island is the Democratic Party (DP), and most other parties originated as split-offs from this party. The personalistic nature of Statian politics means that programmatic differences between the parties are virtually nonexistent, as a result of which political competition is mostly based on personal sentiments and personal relations (Ayisi 1995:68-69). A Dutch civil servant whom I interviewed compared the nonideological nature of Statian politics to regular Dutch municipalities, in which he observed similar dynamics:

In this sense I think it is really village politics. I hate to say it, but I think it is true, because people just don't discuss strategic perspectives and

7 These are the Democratic Party (DP), Progressive Labour Party (PLP), St. Eustatius Empowerment Party (STEP), St. Eustatius Liberal Action Movement (SLAM), United People's Coalition (UPC), and a nameless party spearheaded by Mr. Glenville Schmidt. 


\begin{tabular}{lrcc}
\hline Party & Votes & Percentage & Seats \\
\hline Democratic Party & 473 & 30,0 & 2 \\
Progressive Labour Party & 481 & 30,5 & 2 \\
St. Eustatius Empowerment Party & 133 & 8,4 & - \\
St. Eustatius Liberal Action Movement & 66 & 4,2 & - \\
United People's Coalition & 242 & 15,3 & 1 \\
Nameless List of Glenville Schmidt & 182 & 11,5 & - \\
Total & $\mathbf{1 . 5 8 0}$ & $\mathbf{1 0 0}$ & $\mathbf{5}$ \\
\hline
\end{tabular}

that sort of thing. It is really about the daily poverty, and those kind of things - to look how people can proceed, and where one can get the votes. ${ }^{8}$

The strongly antagonistic political culture of St. Eustatius has resulted in frequent party splits and government collapses, contributing significantly to political instability. The island has witnessed five different executive coalitions in five years, and government collapses were mostly due to personal disagreements and conflicts rather than ideological divisions.

Most respondents agreed that the ideological divisions between Statian political parties are negligible, despite the fact that party labels contain words (such as "progressive" or "liberal") which might indicate an ideological affiliation. In fact, the main rift in Statian politics appears to be between the DP on the one hand, and the other five parties that ran for office on the other. This divide is partially the result of the longstanding dominance of the DP in Statian politics, but is also related to the issue of constitutional status, as the following quote underscores:

Most of the politics on the island revolved around this: it's the DP on one side, and the others on the other side. And this is especially with the constitutional issue, because the DP is the only party that supports the

8 Translated from the original in Dutch: "Wat dat betreft is het toch denk ik echt wel dorpspolitiek. Excusez le mot, maar dat durf ik dan toch wel te zeggen, want over strategische vergezichten en dat soort zaken heeft men het gewoon niet. Het gaat echt over de dagelijkse armoede, over dat soort zaken om te kijken hoe men verder komt, en waar men de stemmen vandaan krijgt." 
status quo as it is. They still do, and all the other parties do not agree with the status as it is now. So in the last election, 70 percent of the people voted for the other parties; 29 percent voted for the DP.

In the lead-up to 10-10-10, the DP conducted the status negotiations on behalf of St. Eustatius, and eventually accepted the present public entity status. While the other parties believe that the current political status of the island is both illegitimate and unsatisfactory, and have therefore advocated new status negotiations, the DP argues that improvements have to made within the public entity status. According to the leader of the party:

As DP I think we are in an exceptional position: also at this election it was five parties against one. And all of the others have the idea of more autonomy in their programs, we were the only party that didn't have that ... That doesn't mean that we are happy with everything, but according to us there is not really an alternative that offers the same assurances and guarantees that we have now.

At present the political status of the island seems to be the only substantive political issue determining party competition. Whereas the DP defends the contemporary status, other parties believe that the current status was imposed on the island by the Dutch government, and is therefore fundamentally illegitimate. According to a politician affiliated with the ruling Progressive Labour Party:

Like we say, it was imposed on us, we never asked for this thing. When we had a referendum we stated our position in 2005, but it seems they have the power to impose. We didn't ask for it, and we still have the right to self-determination, so that should be exercised. And I feel that the people have spoken, and they stated that they want more autonomy. And that's what we want to give them.

\section{The Effects of the 2010 Reforms}

As the discussion above demonstrates, politics on St. Eustatius is traditionally (1) very personal in nature; (2) strongly antagonistic and polarized; and (3) influenced to a significant extent by patron-client relationships between citizens and politicians. In 2010, the island was constitutionally integrated with the Netherlands, and the island administration was reformed along the lines of 
the Dutch municipal model. While politicians before 2010 could be members of both the legislature and the executive, as part of the reforms these functions have become incompatible, and a dualistic system was implemented. In addition, while the administration of St. Eustatius used to fall under the jurisdiction of the Netherlands Antilles, which never really exercised a lot of control over how the island was governed, since 2010 it has fallen directly under the Dutch government in The Hague. In 2010 a number of mechanisms were set up to increase the supervision of good governance on the BES islands, including the appointment of the Kingdom Representative, and the establishment of a board of financial supervision (College financieel toezicht). As a consequence, metropolitan oversight of governance on St. Eustatius has increased significantly. However, while this increased supervision could theoretically result in better governance on the island, thus far it has primarily been a source of tension between the Dutch government and the island government. The implementation of closer financial supervision of the island in June 2015 can be seen as the culmination of these pressures.

According to most interviewees, the Dutch government has enforced too many Dutch laws, norms, and administrative practices on the island as part of the 2010 reforms. As one former island council member indicated:

Holland is trying to take Holland and put it in Statia. It can't work, just like Statia can't fit in Holland. And the laws that govern Holland are not necessarily applicable here as well. And you find that Holland keeps forcing certain laws on us.

Because the politicians of St. Eustatius before 2010 did not face a lot of supervision from the Antillean authorities on Curaçao, the relatively sudden intensification of administrative oversight has caused strain, especially because Dutch or European perspectives on good governance and financial austerity do not necessarily match the local Statian perspectives. As one political activist on the island noted:

That's the Dutch; when it comes to finances, they are very straight. That's good governance to them, but perhaps here it's something different. It doesn't necessarily mean that we have to stay within our budget and that everything has to be in this straightjacket. So I would say we need to define what it is according to us, and we need to stop using terms that are imposed by the motherland to determine what good governance is. That's how I look at that. 
The Statian respondents that I interviewed had very mixed views about the implementation of financial supervision on the island in June 2015. While some island politicians strongly condemned this intervention and portrayed it as tyranny on the part of the Dutch colonial authorities, others believed that the intervention was absolutely necessary, and put the blame on the island politicians who created the financial troubles. The island governor, for example, expressed the following point of view:

I think it [financial supervision] is perhaps a necessary step that allows us to focus on the things that are necessary to strengthen our governmental structure to be able to execute the tasks and responsibilities that we aspire to have. We clearly face challenges now, we have for many years, and I think this is an opportunity for us. However, of course I do understand the politics of it, and the use of rhetoric; nobody likes to be under higher supervision.

The leader of the largest governing party on the island council has been most vocal in his complete rejection of supervision, and invokes terms such as colonialism, racism, and slavery to underscore his denunciation of the Dutch policies implemented in St. Eustatius. In an interview, he stated:

Well, people take it very personally, but I said I am prepared to die for my country. But I also stated that blood will flow on the streets of Statia. Because when I get you, and I push you in the corner, you need to defend yourself. You need to defend yourself, and I will not be responsible if things get out of hand, because the common man in the street, when he cannot take it anymore, when he cannot put bread on the table for his children because he doesn't have a job, I expect that he would rebel, he would react. And so that is why I am saying that Holland is slowly but surely igniting a social revolution in this country.

While other members of the governing coalition use a more moderate discourse to voice their opposition to the perceived Dutch interference, the executive of St. Eustatius has not accepted the supervision, and has refused to cooperate with the Kingdom Representative to solve the island's financial problems.

Another cause for the frustration of many Statian politicians and citizens is the influx of Dutch civil servants, who have assumed positions within the island administration or within the shared service organization, the RCN. According to one local politician, these Dutch administrators have an arrogant mentality that reveals a lack of respect for the island population: 
A lot of them think that they are smarter than you; they look down on you. They don't mix in the community; you see the sort of Apartheid system they create. There are certain areas in the community that they take over during the week.

The wide majority of interview respondents did not share this adversarial attitude toward Dutch civil servants, but many of them did agree that more positions in the administration should be filled by local Statian people. While the island politicians interviewed did not have a particularly negative view of the activities of the RCN, they did complain about the lack of coordination between the RCN and the island government.

While the separation of the legislative and executive administrative branches promulgated in 2010 could theoretically have strengthened good governance on the island, in practice it has primarily resulted in instability. It used to be customary that those who received the most votes at elections would become part of the executive, but under the new rules their political survival is dependent on support in the legislature (island council). In the past five years, personal conflicts have resulted in various party splits and the establishment of new parties, as a result of which the island administration has been overhauled five times. While dualism might work relatively well in Dutch municipalities where programmatic parties compete for seats in the municipal council, in the personalized and polarized political climate of St. Eustatius it has primarily resulted in volatility, arguably undermining the quality of governance. One former island council member explained the problems with dualism:

I have had experience, being in the first island council where you had dualism. But to some extent it is not working the way yet, how it is supposed to under dualism. Our problem is that we are in the very beginning of this dualism thing; we are not completely separate yet. It starts at the head; the island governor cannot and should not be in two bodies, so there we have a problem. He is the chairperson of the executive council, and the chairperson of the island council. So we are talking about dualism here, you know; it's not happening.

A Dutch civil servant who also worked for the local government on St. Eustatius shared this view, and emphasized that the Dutch municipal model is to some extent incompatible with the Caribbean political culture:

What I saw is that this new model of dualism actually did not fit within the culture of the Netherlands Antilles. So that caused a lot of problems, and I 
remember that people had to get used to the fact that the commissioners could no longer be members of the island council. So people really had to get used to the new rules, and even had to learn how to properly conduct an island council meeting. ${ }^{9}$

Like in other small island societies, the lack of investigative journalism on St. Eustatius creates a lack of transparency and enables politicians to hide malpractice (Puppis 2009). The only newspaper available on the island, the Daily Herald, is based and printed in St. Maarten and only pays cursory attention to politics on St. Eustatius. The one reporter on the island working for this newspaper explained the particular challenges to investigative journalism:

It is kind of difficult sometimes because some people do not want to speak with you. Sometimes they don't like things in the paper; if it is about them personally, they don't like things in the paper. I get a lot of accusations about things, because people on the island get the Daily Herald email address. And when they see it they think everything is from me, and it's not. I have been accused a lot, really.

In addition to the Daily Herald, there are two radio stations and two television channels on the island. When it comes to politics, however, both of them principally serve as platforms where politicians present their views, and rarely engage in active journalism. The lack of professionally trained journalists on the island is an obvious cause of this situation, but the lack of funding, the inherently small audience, and the more intimate links between reporters and politicians are some of the other many challenges that Statian media face.

Social media has provided new opportunities for information exchange on the island, and Statians are particularly active on Facebook. Every Statian politician has a personal Facebook account, and some of them use it to keep their constituents updated on the latest political developments. However, in view of the lack of high-quality news media, respondents also complained that a lot of gossip, unsubstantiated rumors, and misinformation is spread on Facebook, which is sometimes hard to correct. Furthermore, the religious and

9 Translated from original Dutch text: "Wat ik zag is dat dit nieuwe model van dualisme eigenlijk niet goed paste in de cultuur van de Nederlandse Antillen. Dus dat leverde veel problemen op, en ik herinner me dat men echt moest wennen was dat de gedeputeerden geen lid van de eilandsraad meer mochten zijn. Dus mensen moesten echt wennen aan de nieuwe regels, en moesten zelfs zoeken naar de manier waarop je überhaupt een vergadering moet houden." 
political divisions that permeate Statian society are mirrored on Facebook, as the following NGO spokesperson explains:

It's funny; there are two forums on Facebook where Statians come, and they meet, and they converse; closed groups. So right now you have this one group who really believes in that ideology, the need to be free, the need to free ourselves from that mental slavery as we talk about it, you know, and to move forward and look after ourselves. But then there is another group, that is saying "no, you guys are racists, that's no way to treat the Dutch." And then what you see, is that indeed that group has the DP supporters, and the other group is a mix of the other political parties.

In sum, while the 2010 reforms have resulted in a number of major institutional changes on St. Eustatius, they do not so far appear to have affected the political culture and traditions of the island. This situation is in line with other studies on institutional transplantation, which highlight the durability of informal political structures and the limited impact of formal rules on how politics is conducted (for the Dutch Caribbean islands, see Mamadouh \& Nauta 2002). While thus having a limited impact on the quality of governance, the reforms have strongly augmented local resistance toward the perceived Dutch "recolonization" ofSt. Eustatius, and may have even strengthened the antagonistic and volatile nature of island politics. If one adopts a broader notion of good governance that also includes political stability, harmony, and effectiveness, the 2010 reforms actually seem to have undermined the quality of governance on St. Eustatius.

\section{Conclusion}

Politics in small island communities is characterized by a number of opportunities and challenges. However, a key difference between sovereign and nonsovereign territories is that in nonsovereign jurisdictions, a larger metropolitan power exercises some degree of control over the quality of governance, and essentially guarantees the maintenance of human rights, democracy, and the rule of law. While this may formally be the case, it is unclear to what extent the presence of a nonsovereign relationship and the type of constitutional relationship with the metropolis actually affect the characteristics of politics and democracy in small island units. In this article, the island of St. Eustatius, a Dutch nonsovereign territory with a bad reputation for governance, was ana- 
lyzed as a case study. The political institutions of this island were dramatically altered as part of the 2010 integration with the Netherlands, and for this reason St. Eustatius constitutes an interesting case for examining the broader notion that political-institutional reforms can have only a limited impact on the quality of governance in small island jurisdictions.

The findings of this article, which are based on two weeks of field research and in-depth interviews with Statian respondents, reveal that the changes of 2010 have not so far succeeded in improving the quality of governance on the island. The implementation of financial supervision of the island in June 2015 can in fact be seen as the culmination of governance problems on the island, and provide the clearest evidence that no improvements have been made in the past five years. While the reforms were only implemented five years ago, and therefore could be considered too recent to have had an impact, the events of the last five years are unambiguously discouraging, and it is hard to envision any positive changes in the near future. Since 2010, political instability and polarization have dramatically increased on the island, as have resentment and bitterness towards the Dutch authorities and civil servants. The new status as a public entity is hotly contested, and in many ways functions as a new political and societal dividing line in an already polarized community.

While this article focused on a single case, there are various indications that its conclusions are applicable to other Caribbean nonsovereign territories as well. In addition to the three public entities, the 2010 reforms in the Dutch Caribbean also created two new autonomous countries, and can therefore be seen as a laboratory case for examining the influence of political-institutional reforms on political cultures and dynamics. Like St. Eustatius, the new status of Curaçao and St. Maarten appears to have weakened the quality of governance so far, and both islands are plagued by instability (especially Curaçao) and corruption scandals (especially St. Maarten). While the five British Overseas Territories (вотs) in the Caribbean have similar governance structures, it appears that some of them (i.e. Anguilla and the British Virgin Islands) have considerably better governance performance than others (i.e. the Turks and Caicos Islands). These observations provide additional evidence for the broader notion that political institutions and structures have a very limited effect on the quality of governance in overseas territories. In order to analyze this hypothesis in more detail, future research on small, nonsovereign island jurisdictions should not be exclusively focused on the bilateral relationship between overseas territories and metropolitan countries, and instead should pay more attention to domestic political dynamics. 


\section{References}

Aldrich, Robert \& John Connell, 1998. The Last Colonies. Cambridge: Cambridge University Press.

Allen, Rose Mary, 2010. The Complexity of National Identity Construction in Curaçao, Dutch Caribbean. European Review of Latin American and Caribbean Studies 89:11725 .

Anckar, Dag, 1999. Homogeneity and Smallness: Dahl and Tufte Revisited. Scandinavian Political Studies 22(1):29-44.

Anckar, Dag, 2002. Why Are Small Island States Democracies? The Round Table: The Commonwealth Journal of International Affairs 91(365):375-90.

Ayisi, Eric O., 1995. St. Eustatius: The Treasure Island of the Caribbean. Trenton NJ: Africa World Press.

Baldacchino, Godfrey, 2012. Islands and Despots. Commonwealth and Comparative Politics 50(1):103-20.

Baldacchino, Godfrey \& David Milne, 2006. Exploring Sub-National Island Jurisdictions: An Editorial Introduction. The Round Table: The Commonwealth Journal of International Affairs 95(386):487-502.

Baldacchino, Godfrey \& David Milne (eds.), 2009. The Case for Non-Sovereignty: Lessons from Sub-National Island Jurisdictions. London: Routledge.

Bonilla, Yarimar, 2015. Non-Sovereign Futures: French Caribbean Politics in the Wake of Disenchantment. Chicago: University of Chicago Press.

Bor, Wout van den, 1979. Eiland op drift: De sociale organisatie van een kleine Caribische samenleving: St. Eustatius. Wageningen, the Netherlands: Landbouwhogeschool.

Chittoo, Hemant B., 2011. Public Administration in "Small and Island Developing States": A Debate about Implications of Smallness. Global Journal of Management and Business Research 11(9):23-34.

Clegg, Peter \& Peter Gold, 2012. The UK Overseas Territories: A Decade of Progress and Prosperity? In: Peter Clegg \& David Killingray (eds.), The Non-Independent Territories of the Caribbean and Pacific: Continuity or Change? London: Institute of Commonwealth Studies, pp. 19-39.

Clegg, Peter \& David Killingray (eds.), 2012. The Non-Independent Territories of the Caribbean and Pacific: Continuity or Change? London: Institute of Commonwealth Studies.

Congdon Fors, Heather, 2014. Do Island States Have Better Institutions? Journal of Comparative Economics 42(1):34-6o.

Corbin, Carlyle, 2012a. Self-Determination after Partial Integration: Sint Eustatius. Overseas Territories Report. http://overseasreview.blogspot.nl/2012/07/self -determination-after-partial.html.

Corbin, Carlyle, 2012b. Self-Governance Deficits in Caribbean Non-Independent Countries. In: Peter Clegg \& David Killingray (eds.), The Non-Independent Territories of the 
Caribbean and Pacific: Continuity or Change? London: Institute of Commonwealth Studies, pp. 163-93.

Dahl, Robert A. \& Edward R. Tufte, 1973. Size and Democracy. Stanford CA: Stanford University Press.

Daniel, Justin, 2005. The French Départements d'Outre Mer: Guadeloupe and Martinique. In: Lammert de Jong \& Dirk Kruijt (eds.), Extended Statehood in the Caribbean: Paradoxes of Quasi Colonialism, Local Autonomy, and Extended Statehood in the USA, French, Dutch, and British Caribbean. Amsterdam: Rozenberg Publishers, pp. 69-84.

Diamond, Larry with Svetlana Tsalik, 1999. Size and Democracy: The Case for Decentralization. In: Larry Diamond (ed.), Developing Democracy: Toward Consolidation. Baltimore MD: Johns Hopkins University Press, pp. 117-6o.

Duijf, Charlotte M.A.M. \& Fred H.A. Soons, 2011. The Right to Self-Determination and the Dissolution of the Netherlands Antilles. Nijmegen, the Netherlands: Wolf Legal Publishers.

Farrugia, Charles, 1993. The Special Working Environment of Senior Administrators in Small States. World Development 21(2):221-26.

Hall, Stuart, 2005. Negotiating Caribbean Identities. New Left Review 209:3-14.

Hillebrink, Steven, 2008. The Right to Self-Determination and Post-Colonial Governance: The Case of the Netherlands Antilles and Aruba. The Hague: T.M.C. Asser Press.

Hintjens, Helen, 1997. Governance Options in Europe's Caribbean Dependencies: The End of Independence. The Round Table: The Commonwealth Journal of International Affairs 86(344):533-47.

Jong, Lammert de, 2009. The Implosion of the Netherlands Antilles. In: Peter Clegg \& Emilio Pantojas-García (eds.), Governance in the Non-Independent Caribbean. Kingston: Ian Randle Publishers, pp. 24-44.

Klomp, Ank, 1983. Politiek op Bonaire: Een antropologische studie. Utrecht, the Netherlands: Instituut voor Culturele Antropologie.

Lijphart, Arend, 1977. Democracy in Plural Societies: A Comparative Exploration. New Haven CT: Yale University Press.

Mamadouh, Virginie \& Oberon Nauta, 2002. Bringing Democracy to “The West": Democratic Institutions and Good Governance in the Netherlands Antilles. In: Martin de Jong, Konstantinos Lalenis \& Virginie Mamadouh (eds.), The Theory and Practice of Institutional Transplantation: Experiences with the Transfer of Policy Institutions. Dordrecht, the Netherlands: Kluwer Academic Publishers, pp. 139-57.

Oostindie, Gert \& Inge Klinkers, 2003. Decolonising the Caribbean: Dutch Policies in a Comparative Perspective. Amsterdam: Amsterdam University Press.

Oostindie, Gert \& Inge Klinkers, 2012. Gedeeld koninkrijk: De ontmanteling van de Nederlandse Antillen en de vernieuwing van de trans-Atlantische relaties. Amsterdam: Amsterdam University Press. 
Puppis, Manuel, 2009. Media Regulation in Small States. International Communication Gazette 71(1-2):7-17.

Ramos, Aarón \& Angel Rivera, 2001. Islands at the Crossroads: Politics in the NonIndependent Caribbean. Boulder CO: Lynne Rienner Publishers.

Remmer, Karen, 2010. Political Scale and Electoral Turnout: Evidence From the Less Industrialized World. Comparative Political Studies 43(3):275-303.

Rezvani, David A., 2014. Surpassing the Sovereign State: The Wealth, Self-Rule, and Security Advantages of Partially Independent Territories. Oxford: Oxford University Press.

Richards, Jeffrey, 1982. Politics in Small Independent Communities: Conflict or Consensus? Journal of Commonwealth and Comparative Politics 20(2):155-71.

Roitman, Jessica Vance \& Han Jordaan, 2015. Fighting a Foregone Conclusion: Local Interest Groups, West Indian Merchants, and St. Eustatius, 1780-1810. Tijdschrift voor Sociale en Economische Geschiedenis 12(1):79-100.

Sluis, Miriam, 2004. De Antillen bestaan niet: De nadagen van een fictief land. Amsterdam: Bert Bakker.

Spies, J.W.E., A.H.A. Soons, G.A.E. Thodé, L.F.M. Verhey \& F.H.H. Weekers, 2015. Vijfjaar verbonden: Bonaire, Sint Eustatius, Saba en Europees Nederland. [Evaluation report.] The Hague: Ministerie van Binnenlandse Zaken en Koninkrijksrelaties.

Sutton, Paul, 2007a. Democracy and Good Governance in Small States. In: Eliawony Kisanga \& Sarah Jane Danchie (eds.), Commonwealth Small States: Issues and Prospects. London: Commonwealth Secretariat, pp. 201-17.

Sutton, Paul, 2007b. Public Sector Reform in Small States: Cases from the Commonwealth Caribbean. In: Eliawony Kisanga \& Sarah Jane Danchie (eds.), Commonwealth Small States: Issues and Prospects. London: Commonwealth Secretariat, pp. $218-35$.

Veenendaal, Wouter, 2013. Political Representation in Microstates: The Cases of St. Kitts and Nevis, Seychelles, and Palau. Comparative Politics 45(4):437-56.

Veenendaal, Wouter, 2014. Politics and Democracy in Microstates. London: Routledge.

Veenendaal, Wouter, 2015. The Dutch Caribbean Municipalities in Comparative Perspective. Island Studies Journal 10(1):15-30.

Veenendaal, Wouter, 2016. Smallness and Status Debates in Overseas Territories: Evidence from the Dutch Caribbean. Geopolitics 21(1):148-70. 